\title{
THE INFLUENCE OF TECHNICAL INEFFICIENCY LEVEL THAT INVOLVE FARMER'S BEHAVIOUR ON RISK TOWARDS PROFIT IN RICE PRODUCTION OF INDONESIA
}

\author{
Shinta Agustina \\ Faculty of Agriculture, University of Brawijaya, Indonesia \\ E-mail: shint471ub@yahoo.com, agustinafp@ub.ac.id
}

\begin{abstract}
This paper analyses the influence of the level of technical inefficiency that occur in farmers on profits earned. Where the level of technical inefficiency consider that factor of managerial capabilities of farmers, one of which is a farmer's behaviour in dealing with the risks of farming. The aims of this research are to analyse the influence of the level of technical inefficiency on profits and perform simulations to determine the strategic policies that can be done by the government for an increase in profits of rice farmers. The methods used are the method of Translog Stochastic Profit Frontier and share of expenditure for inputs against profit. Primary data by panel collected during the rainy season and the dry season in 2014/2015 with the number of observations for 610 farmers. The research area covers 7 subdistricts in Malang Regency, East Java Province, Indonesia. The results showed that there is influence negatively the level of technical inefficiency and significant with a profit of 2.61. The best policy is the provision of a hand tractor to farmer group and efforts to reduce the level of technical inefficiency through increasing attitudes and behaviour of farmers in dealing with the risks of farming with the changes increase in profit of $29.12 \%$.
\end{abstract}

\section{KEY WORDS}

Risk behaviour, panel data, translog stochastic profit function, farming policy.

The stability of food supply is essential, if there is a deficit of stocks of foodstuffs would suck up the foreign exchange sizeable. Currently, the Indonesian government continuously intensified programs to achieve rice self-sufficiency next 3 years. Growth in the number of Indonesia's population continues to increase by $1.49 \%$ during 2000 to 2010 (Statistics Indonesia, 2011) so the rice consumption continues to increase. Consumption in Indonesia is still high in foodstuffs of rice compared to other countries (despite the downward trend in rice consumption from 2009 to 2013 amounted to $1.62 \%$ ). In 2009, rice consumption as many $91.3 \mathrm{~kg} /$ capita / year, then declined to $85.5 \mathrm{~kg} /$ capita / year in 2013 (Statistics Indonesia, 2013), however Indonesia's rice consumption is still above the average consumption of rice of the Asian population, for example Korea of $40 \mathrm{~kg} /$ capita / year, Japan of $50 \mathrm{~kg} /$ capita / year, Malaysia of $80 \mathrm{~kg} /$ capita / year and Thailand of $70 \mathrm{~kg} /$ capita / year (Sulihanti, S., 2013). According to Respati, E., (2013) the total requirement of consumer society and industry based processed rice about $97.6 \mathrm{~kg} /$ capita / year in 2013 and in 2014 amounted to $97.4 \mathrm{~kg} /$ capita / year.

National rice production in 2013 of 71.279 million tons with the harvest area is 13,835,252 hectares (Statistics Indonesia, 2014). While the rice harvest area from 2000 to 2014 in Indonesia did not show a significant increase only 1\%. Productivity of rice in Indonesia average of 50.6 quintal / hectare with an average rate of $1.44 \%$ from 2000 to 2014 , while the Ministry of Agriculture has a target in 2014, productivity of rice in Indonesia could reach 60-70 quintal / hectare. East Java Province is the second largest producer of rice in Indonesia, but a fixed value in 2013 as many as 12.05 million tons of rice dry milling, decreased by 149260 tonnes or about $-1.22 \%$ compared to the year 2012 , this was due to a decrease in productivity of 2.29 quintal / hectare or about $-4.20 \%$, although the harvested area increased by $3.1 \%$. Several regencies / cities experiencing a shortage of rice due to more demand for rice than the resulting production, one of which is Malang Regency. The condition is equal to Malang Regency, although the highest productivity above the average of national and provincial namely by 62.3 quintal / hectare, but the lack of production and 
fluctuations in the rate of productivity growth occurs. In 2010 in Malang Regency with a population of $2,413,779$, the rice the needs of 306,549 tonnes and total production of 263,162 tonnes (Statistics Indonesia of East Java Province, 2013) or from different sources the number of rice production of 284,833 (Agriculture Agency of Malang Regency, 2011) resulting in a shortage of 43387 tonnes or 21716 tonnes. In the following years, the production of rice in Malang Regency continued to decline.

Fluctuations in the growth of productivity above, one of them caused by the behaviour of farmers in decision making when using input. Decisions concerning the application of the technology is based on the possibility of farming the risk that will be faced affect the allocation of inputs. Farmer's behaviour in dealing with the risk often encountered is behaviours that are reluctant face the risk or prefer to avoid the risk or risk averter (Agustina Shinta $\left.{ }^{1}, 2006\right)$. The use of production factors that are inconsistent with suggestion program hence causing the maximum production cannot be achieved by the farmers. Rice farmers in Malang regency achieve technical efficiency of $76.5 \%$ (Agustina Shinta ${ }^{2}, 2006$ ) so there is still a chance to increase the maximum production of $23.5 \%$, or called there is still technical efficiency.

Kumbakhar (2002) states that the production of a commodity affected by whether or not efficient of farmers in the allocation of production inputs and technical inefficiency problems related to the managerial capability of farmers. Bokhuseva and Hockman (2004) also states that one of the factors causing the decline in production is the technical inefficiency. Farmers confronted with the series of choices about how to allocate its resources to produce alternative products that may be produced with the aim of maximize the profit. Production risk is the uncertainty aspect of production which is very important in the formulation of government policy and decision-making by farmers (Just and Pope (1978), Griffiths and Anderson (1982) and Guan H.Wan, et al., (1992)). According Battese, et al., (1994) that insert the risk of production in the stochastic frontier production function is the essence matter that associated with the prediction of technical efficiency, because the measurement of technical efficiency measures the degree of usefulness of the technology adopted in the production process.

Consideration of variables risk behaviour of farmers against a profit (performed by Foster and Rausser (1991)) and considerations incorporate technical inefficiency (performed by Abrar, (2001); Arnade and Trueblood (2002); Kumbhakar and Tsionas (2008); and Garshasbi, et al., (2010)) against a profit. Translog profit function models in this research will insert technical inefficiency of variables explicitly, while the farmer's behaviour in the face of risk has been implicitly included in the calculation of inefficiency because it is a managerial capability of farmers.

Associated with the above problems, the allocation of input use is essential in an effort to increase the production potential without neglecting the farmer's behaviour in the face of risk in the measurement of technical inefficiency, so that it can provide valid information about how government policies are applied. Thus this research aims to analyse the influence of the level of technical inefficiency on profits and perform simulations to determine the strategic policies that can be done by the government so that an increase in profits of rice farmers.

\section{MATERIALS AND METHODS}

Study Area. Location of research conducted by purposive in Malang Regency, East Java, Indonesia, considering that East Java is the centre of the highest rice after West Java while Malang Regency is a high productivity in East Java, but a trend fluctuation of the rate of productivity of rice were sharply during 2000-2013. The average productivity of rice for 13 years in Malang Regency reached 6,125 tons / ha, while the average productivity of East Java at 5:48 tons / ha and the national average of 4.73 tons / ha. Subdistrict was chosen for the example is that a subdistrict that-productivity above the average productivity of rice across Malang Regency because they have the opportunity to become self-sufficient area to fulfil the region, but the fluctuation of production and the rate of productivity growth sharply. 
Time Determination Methods. The research was conducted in two stages, the first stage is the study of literature and secondary data collection obtained from various agencies carried out in January - March 2014 and the second stage is to collect primary data held during the harvest season in October 2014 to collect data recall previous seasons: the rainy season from October to March 2013 and the data for the dry season in April-September, 2014.

Data Analysis Methods. Methods to measure the behaviour of farmers in the face of risk can be seen in the article Agustina Shinta ${ }^{1}$, et al. (2016) and the method of measuring the level of technical efficiency can be read in the article Agustina Shinta ${ }^{2}$, et al. (2016). In this paper, the model formulation of profit rice farming using Translog Stochastic Profit Frontier the share of expenditure for the inputs and share for outputs against profit. Estimates will be done by three restrictions as follows: Young's Theorem on the assumption of homogeneity means that $\sum_{\mathrm{j}=1}^{\mathrm{n}} \beta_{\mathrm{ij}}=0$; all parameters $\mathrm{i}$ and $\mathrm{j}$ are estimated in the equation equal to zero and linearity meaning that $\sum_{\mathrm{j}=1}^{\mathrm{n}} \beta_{0}=1$; summation intercept in all equations equal to one.

Specifications model formulated in this research are over-identified conditions because the number of variables in the model amounted to $261(\mathrm{k}=261)$, the number of endogenous and exogenous variables in a specific equations in the model amounted to $11(M=11)$ and the number of equation of in the model or the number of endogenous variables in the model amounted to $13(\mathrm{G}=13)$. Thus $(\mathrm{K}-\mathrm{M})>(\mathrm{G}-1)$ is over-identified, therefore the estimation of parameters using the SUR (seemingly unrelated regression estimation) that will be analysed using SAS software. SUR method provides high efficiency in simultaneous estimation, as many as 1 equation of profit function, 11 equations of share of expenditure for inputs and one equation of share of output against profit allegedly simultaneously with the restrictions of linearity, symmetry and homogeneity.

To examine the accuracy of the model and the influence of exogenous variables and predetermine variables against endogenous variables, it is necessary F-test and t-test. Measurement used to measure the closeness between the predicted value on the model and the actual value among other measures RMSPE (Root Mean Squares Error Percent) U-theil coefficient and its decomposition. Once the model is said to be precise, then can be done a simulation of the model policy. The variables used in model formulation are summarized in Appendix 1 and the profit model formulations are summarized in Appendix 2.

\section{RESULTS AND DISCUSSION}

Sample Characteristics. The level of technical efficiency of farming has been analysed using a method TRANSLOG Stochastic Productivity Frontier by considering the behaviour of farmers in dealing with the risks of farming on a previous paper by the author. The summary can be seen in Table 1.

Table 1 - Distribution of Efficiency Level of Farmers Based on Risk of Behaviour (\%)

\begin{tabular}{lllllll}
\hline Categories & \multicolumn{2}{l}{ Rainy Season } & \multicolumn{5}{l}{ Dry Season } \\
\cline { 2 - 7 } & Risk averter & Risk neutral & Risk taker & Risk averter & Risk neutral & Risk taker \\
\hline \hline $0.31-0.51$ & 10.13 & - & - & 11.39 & - & - \\
$0.52-0.72$ & 26.58 & - & 20.97 & 30.38 & - & 1.61 \\
$0.73-0.95$ & 63.29 & 100 & 79.03 & 58.23 & 100 & 98.39 \\
\hline \hline
\end{tabular}

The behaviour of farmers unwilling to face the risk of achieving an efficiency of $73-95 \%$ as many as 63.29 in the rainy season and $58.23 \%$ in the dry season. For farmers who fall into the category of risk neutral and risk takers outnumber that can achieve higher levels of efficiency. In the Table 2 to 8 are the example of characteristics of the sample in the use of inputs based on risk behaviour, presented in Appendix 3.

Analysis Results of Technical Inefficiency Level Towards Profit. The level of technical efficiency has been obtained from measurements in the previous paper, then to find the level of technical inefficiency is 1 - the achievement of technical efficiency. Data the level of these 
technical inefficiencies will be included in the analysis of farming profit. Translog profit function that takes into account the level of technical inefficiency is estimated using SUR (seemingly unrelated regression) which requires a two-stage estimation, namely the first stage, residual OLS is used to estimate the cross-equation error covariances, The second stage is estimated through regression parameter using the generalized least squares estimation of covariance. If the cross-equation error covariances is zero, the estimated OLS and SUR become equivalent. If the cross-equation error covariances is not zero, the estimated SUR has a standard error smaller than the OLS estimates (Sitepu, 2002).

Process analysis is then performed not by pooling data because of the limitations of ownership of software, so using cross section data with the support of a dummy 2 planting season. Translog profit function is analysed simultaneously with the share of expenditure for the inputs and production against profit with the restrictions / limitations of linearity, homogeneity and symmetrical. Analysis of the labors of men and women together into labor variable, because the wages of male labor and the wages of women workers who are not much different causing regression analysis violates the assumption of multicollinearity.

Table 9 - Profit Function with Consideration of Technical In-Efficiency Levels

\begin{tabular}{|c|c|c|c|c|c|c|c|c|}
\hline No & Variables & $\begin{array}{l}\text { Estimated } \\
\text { Parameters }\end{array}$ & No & Variables & $\begin{array}{l}\text { Estimated } \\
\text { Parameters }\end{array}$ & No & Variables & $\begin{array}{l}\text { Estimated } \\
\text { Parameters }\end{array}$ \\
\hline 1 & Intercep & $2.275^{* * * *}$ & 29 & InPBoPTKo & $0.013^{\star \star \star \star}$ & 57 & InPPSoZ2o & $0.0067^{\star \star \star \star}$ \\
\hline 2 & LnPBo & $0.369^{* * * *}$ & 30 & InPBoPOBKo & $0.0028^{*}$ & 58 & InPSPoPOo & $-0.033^{*}$ \\
\hline 3 & LnPUo & $-0.38^{* * * *}$ & 31 & InPBoPOBLo & $0.007^{* \star * \star}$ & 59 & InPSPoPTKo & $0.258^{* * * *}$ \\
\hline 4 & InPZAo & $-0.675^{\star * \star *}$ & 32 & InPBoZ1o & $1.28 \mathrm{E}-06$ & 60 & InPSPOPOBKo & $0.00168^{* * * *}$ \\
\hline 5 & InPPSo & $-1.06^{* * * *}$ & 33 & InPBoZ2o & $0.00226^{* * * *}$ & 61 & InPSPoPOBLo & $0.00052^{* * * *}$ \\
\hline 6 & InPSPo & $-0.39^{* * * *}$ & 34 & InPUoPZAo & $0.1762^{\star \star \star \star}$ & 62 & InPSPoZ1o & $0.0167^{\star \star \star *}$ \\
\hline 7 & LnPOo & $-1.91^{* * * *}$ & 35 & InPUoPPSo & $0.1318^{* \star * *}$ & 63 & InPSPoZ2o & $0.0025^{\star * * *}$ \\
\hline 8 & InPTKo & $3.639^{* * * *}$ & 36 & InPUoPSPo & $0.1399^{\star \star \star *}$ & 64 & InPOoPTKo & $0.2765^{\star \star \star \star}$ \\
\hline 9 & InPOBKo & $0.642^{* * * *}$ & 37 & InPUoPOo & $0.0166^{\star \star \star *}$ & 65 & InPOoPOBKo & $0.1689^{\star \star \star *}$ \\
\hline 10 & InPOBL & $-0.097^{\star \star \star \star}$ & 38 & InPUoPTKo & $0.0442^{\star \star \star \star}$ & 66 & InPOoPOBLo & $-0.0397^{* * * *}$ \\
\hline 11 & InZ10 & $0.7277^{* * * *}$ & 39 & InPUoPOBKo & $-0.0054^{* * * *}$ & 67 & InPOoZ1o & $0.023^{\star * * *}$ \\
\hline 12 & InZ2o & $-0.254^{* * * *}$ & 40 & InPUoPOBLo & $0.005^{\star * \star *}$ & 68 & InPOoZ2o & $0.057^{* * * *}$ \\
\hline 13 & $\ln \mathrm{PBo} 2$ & $-0.29^{* * * *}$ & 41 & InPUoZ1o & $0.005^{* * * *}$ & 69 & InPTKоРОВКо & $-0.023^{* * * *}$ \\
\hline 14 & InPUo2 & $-0.561^{* \star \star *}$ & 42 & InPUoZ2o & $-0.0014^{* * * *}$ & 70 & InPTKoPOBLo & 0.006 \\
\hline 15 & InPZAo2 & $-0.415^{\star \star \star \star}$ & 43 & InPZAoPPSo & $0.1255^{\star * \star *}$ & 71 & InPTKoZ1o & $0.0066^{\star * * *}$ \\
\hline 16 & InPPSo2 & $-0.522^{\star \star \star \star}$ & 44 & InPZAoPSPo & $-0.148^{\star \star \star *}$ & 72 & InPTKoZ2o & $0.0074^{\star * * *}$ \\
\hline 17 & InPSPo2 & $-0.4479^{* * * *}$ & 45 & InPZAoPOo & -0.018 & 73 & InPOBKoPOBLo & 0.00229 \\
\hline 18 & InPOo2 & $-0.272^{\star * \star \star}$ & 46 & InPZAoPTKo & $0.181^{* \star \star *}$ & 74 & InPOBKoZ1o & $0.008^{* \star \star *}$ \\
\hline 19 & InPTKo2 & $-0.992^{\star * \star *}$ & 47 & InPZAoPOBKo & -0.0115 & 75 & InPOBKoZ2o & $0.0159^{\star * * *}$ \\
\hline 20 & InPOBKo2 & $-0.147^{\star \star \star \star}$ & 48 & InPZAoPOBLo & -0.00788 & 76 & InPOBLoZ1o & $0.0054^{* * * *}$ \\
\hline 21 & InPOBLo2 & 0.00149 & 49 & InPZAoZ1o & $0.0322^{\star \star \star \star}$ & 77 & InPOBLoZ2o & $0.0143^{* * * *}$ \\
\hline 22 & $\operatorname{lnZ102}$ & $-0.1225^{* * * *}$ & 50 & InPZAoZ2o & $0.0074^{* * * *}$ & 78 & Inz1oz2o & $0.0022^{\star * * *}$ \\
\hline 23 & $\operatorname{lnZ2o} 2$ & $-0.114^{\star * * *}$ & 51 & InPPSoPSPo & $0.1169^{\star \star \star \star}$ & 79 & Dtehn & $0.07^{* * * *}$ \\
\hline 24 & InPBoPUo & $0.049^{* * * *}$ & 52 & InPPSoPOo & $-0.1597^{\star * * *}$ & 80 & leff & $-2.61^{* * * *}$ \\
\hline 25 & InPBoPZAo & $0.078^{* * * *}$ & 53 & InPPSoPTKo & $0.2226^{\star \star \star \star}$ & 82 & $\mathrm{dmt}$ & -0.002 \\
\hline 26 & InPBoPPSo & $0.063^{* * * *}$ & 54 & InPPSoPOBKo & $-0.0126^{*}$ & & & \\
\hline 27 & InPBoPSPo & $0.09^{* \star * \star}$ & 55 & InPPSoPOBLo & $0.005^{\star * \star *}$ & & & \\
\hline 28 & InPBoPOo & $-0.019^{* * * *}$ & 56 & InPPSoZ1o & $0.0226^{\star * \star *}$ & & & \\
\hline
\end{tabular}

Notes : F-value $35.78(<0.0001) ; R^{2}=0.82 ; d w=1.658$

$* * * *, * *$ * ; confidence level $99 \%, 97.5 \%$ and $90 \%$.

Profit Translog Model analysed simultaneously with 13 equation of share of input costs against profit. So that the model used 13 endogenous variables, 261 parameters and 13 structural equations, the results of model analysis shows the variation of $R^{2}$ varies between $17 \%$ and $99.1 \%$. $R^{2}$ indicates that the amount of the contribution of the explanatory variables and exogenous in the equation against variation in the endogenous variables. Statistical tests using the F-test shows that the explanatory variables on all structural equations influence simultaneously convincingly confidence level of over $99 \%$. $\mathrm{R}^{2}$ obtained is high at 0.82 , meaning that the variables in the model indicates that the amount of the contribution of the explanatory variables and exogenous in the equation against variation in the endogenous variables, while the F-value of 35.78 and the Durbin Watson at 1,658. The results of analysis 
with 81 parameters indicate as many as 10 parameters that do not affect the endogenous variables where the parameter is suggestive of exogenous variables dummy growing season and another constitute allegation of predetermined variables of equations of translog profit model that considers levels of technical inefficiency. The exogenous variables included in the equation are the dummy technology, the level of technical inefficiency and dummy growing season. Dummy technology shows the differences in the optimal profits obtained by farmers as a result of the application of technology. Technical inefficiency variables shown to affect negatively on optimal profits, the higher the level of inefficiency by $1 \%$, it will decrease the optimal profit of farmers amounted to $2,618 \%$, presented in Table 9.

Analysis of the profit function, would be more appropriate when using calculations share of input expenditure against profits. Results of analysis for the share of expenditure for inputs against profit presented in Appendix 4.

The Results of Simulation Determines the Policy to Increase Profit of Rice Farmers. Before carrying out the simulation, the model of translog profit function, share of expenditure for inputs and share of output against profit required validation procedures beforehand in order that the predicted value produced does not deviate from the actual value. Results of analysis of the value of the U-Theil generates between $0.01-0.4$; UM values between 0.0 0.82 ; US values between 0:01 to $0: 41$, while the values of UC between $0.18-0.93$. Value of $\mathrm{U}$-Theil and UM almost zero and the value of UC close to one; only on SYpr equation that generates the value of the U-Theil (0:03), UM value (0.82), and the value of UC is a bit far from the one that is 0.18 . From this analysis, then the model function in rice farming profit above can be used for simulation. Simulation scenarios are divided into two single simulation and double simulation, presented in the following table:

Table 10 - Impact of Single and Double Policy Simulations That Change in Profits

\begin{tabular}{|c|c|c|c|c|c|}
\hline No & Scenarios & $\begin{array}{l}\text { Basic } \\
\text { Estimations }\end{array}$ & $\begin{array}{l}\text { Prediction } \\
\text { Estimation }\end{array}$ & $\begin{array}{l}\text { Changes in } \\
\text { Profits }\end{array}$ & Ranking \\
\hline & Single & & & & \\
\hline 1 & Sim 1 (HPP 15\%) & $17,194,427$ & $20,234,424$ & 15.02 & 8 \\
\hline 2 & Sim 2 (Subsidy of Px 25\%) & $17,194,427$ & $17,543,532$ & 1.99 & 13 \\
\hline 3 & $\operatorname{Sim} 3(\mathrm{HT})$ & $17,194,427$ & $17,582,170$ & 2.21 & 12 \\
\hline $4 a$. & Sim 4a (Ineff Pend) & $17,194,427$ & $20,103,327$ & 14.47 & 7 \\
\hline \multirow[t]{2}{*}{ b. } & Sim 4b (Ineff PR) & $17,194,427$ & $20,534,067$ & 16.26 & 6 \\
\hline & Double & & & & \\
\hline 5 & Sim 1 dan 2 (HPP and Subsidy) & $14,951,065$ & $16,109,116$ & 7.19 & 10 \\
\hline 6 & Sim 1 dan 3 (HPP and HT) & $14,951,065$ & $16,149,439$ & 7.42 & 9 \\
\hline $7 a$ & Sim 1 dan $4 a$ (HPP and InefPend) & $14,951,065$ & $18,463,306$ & 19.02 & 5 \\
\hline b. & Sim 1 dan $4 b$ (HPP and InefPR) & $14,951,065$ & $18,727,610$ & 20.17 & 4 \\
\hline 8 & Sim 2 dan 3 (Subsidy and HT) & $14,951,065$ & $19,052,252$ & 21.53 & 3 \\
\hline 9a. & Sim 2 dan $4 a$ (Subsidy and InefPend) & $17,194,427$ & $17,428,126$ & 1.34 & 14 \\
\hline b. & Sim 2 dan $4 b$ (Subsidy and InefPR) & $17,194,427$ & $17,801,546$ & 3.41 & 11 \\
\hline $10 a$. & Sim 3 dan $4 a$ (HT and InefPend) & $17,194,427$ & $23,752,441$ & 27.61 & 2 \\
\hline b. & Sim 3 dan 4b (HT and inefPR) & $17,194,427$ & $24,258,943$ & 29.12 & 1 \\
\hline
\end{tabular}

Single policy simulation results shown that increasing farmers' profits can be acquired highest by efforts to reduce technical inefficiency through improved managerial capabilities of farmers namely to increase farmers' attitudes and behaviour in the face of the risks of farming. While the double policy simulation results highest increase in profit is the policy of hand tractor support to farmers' groups and efforts to reduce technical inefficiency through improved managerial capacity of farmers namely to increase farmers' attitudes and behaviour in the face of the risks of farming.

\section{CONCLUSIONS}

Based on the research that has been done, the conclusion can be formulated as follows: the level of technical inefficiency that occurs in rice farming in Malang Regency will significantly affect the achievement of a profit of -2.61 . This means that the higher the level of 
technical inefficiency single digit then the decrease a profit of 2.61 and simulation scenarios either single or double may give impact to increased profits on rice farmers between $1.99 \%$ $29.12 \%$. The best single policy simulation is an effort to decrease the level of technical inefficiency through the improvement managerial capacity of farmers, which is the attitude and behaviour of farmers in dealing with risks of farming with the changes increase profit of $16.26 \%$. While the double policy simulation is best of hand tractor support to farmer group in order to reduce the cost of renting a tractor and efforts to reduce the level of technical inefficiency through increasing farmers' attitudes and behaviour in the face of the risk of farming with changes increase profit of $29.12 \%$.

\section{POLICY IMPLICATIONS}

The implications for the government policy is how to increase the courage to take decisions in the allocation of input that is with training, informal education (Integrated Pest Management Field School, Integrated Crop Management Field School), counseling, and mentoring of technology, so that the information to induction of technology to be precise by farmers, policy in facilitating access to credit through local financial institutions, policy easy access / pricing information system through the department of agriculture and immediately apply to the whole area of insurance, for farmers to take the risk to produce because they feel safe and protected crop from plant pests and natural events.

\section{REFERENCES}

1. Abrar S, 2000. Estimating Supply Response in The Presence of Technical Inefficiency Using the Profit Function: An Aplication to Ethiopian Agriculture. University of Leicester. UK

2. Agustina Shinta, Budi Setiawan, Ratya Anindita, and Syafrial. 2016. Incorporating Risk Preferences of Farmers and Technology in Analyzing The Total Factor Productivity of Rice Farming in Malang,Indonesia, RJOAS,1(49), January: pp. 47-56

3. Agustina Shinta, Budi Setiawan, Ratya Anindita, and Syafrial. 2016. Measurement of Technical Efficiency that Involving Farmers Preferences towards Risk of Rice Farming in Malang (Indonesia), RJOAS, 3(51), March: pp. 3-13

4. Aigner D, C.A.Knox Lovell and Peter Schmidt, 1977. Formulation and Estimation of Stochastic Frontier Production Function Models. Journal of Econometrics 6, pp. 21-37. North-Holland Publishing Company

5. Arnade $C$ and Michael A.Trueblood, 2002. Estimating a Profit Function in the Presence of Inefficiency: An Aplication to Russian Agriculture. Journal of Agricultural and Resource Economics 27(1): 94-113

6. Athipanyakul T, et al, 2014. Key Factors for Improving Technical Efficiency of Upland Rice Production. American Journal of Applied Sciences 11 (2): 266-272

7. Badan Pusat Statistik (Statistics Indonesia), 2011. Statistics Indonesia, Available in www.bps.go.id

8. Badan Pusat Statistik Kabupaten Malang (Statistics Indonesia of Malang Regency), 2013. Statistik Kabupaten Malang (Statistics of Malang Regency), Available in www.malangkab.bps.go.id

9. Badan Pusat Statistik (Statistics Indonesia), 2013. Sensus Ekonomi Nasional 2009-2013 (National Economics Census in 2009-2013). Statistics Indonesia, Available in www.bps.go.id

10. Badan Pusat Statistik (Statistics Indonesia), 2014. Statistics Indonesia, tersedia di www.bps.go.id

11. Badan Pusat Statistik Propinsi Jawa Timur (Statistics Indonesia of East Java Province, 2013, Statistik Jawa Timur (Statistics of East Java), Available in www.jatim.bps.go.id

12. Bokhuseva, R. and H. Hockmann. 2004. Output Volatility in Russian Agriculture: The Significance of Risk and Inefficiency. Working Paper. Institute of Agricultural Development in Central and Eastern Europe (IOMA), Halle. 
13. Case and Fair, 2007. Prinsip - Prinsip Ekonomi (The Principles of Economics). Jilid 1 (First Edition). Penerbit Erlangga. Jakarta

14. Chambers, R.G., 1988. Applied Production Analysis. A dual Approach. Cambridge University Press. New York.

15. Christensen, L.R., Jorgensen D.W., and Lau L.J. 1973. Trancedental Logarithmic Production Frontier. Economics and Statistics Journal, Vol 55, Issue 1 (Feb 1973), pp. 28-45

16. Coelli, T. 1995. Recent Developments in Frontier Modelling and Efficiency Measurement. Australian Journal of Agricultural Economics, Vol. 39, No.3, Pp. 219-245

17. Coelli, T. 2005. An Introduction to Efficiency and Productivity Analysis. Second Edition. Springer. USA

18. Foster,W.E and G.C.Rausser (1991). Farm Behaviour Underrisk of Failure. American Journal of Agricultural Economics.

19. G.E.Battese, A.N.Rambaldi ans G.H.Wan, 1994. A Stochastic Frontier Production Function with Flexible Risk Properties. Paper presented at The Georgia Productivity Workhsop,

20. G.E.Battese and T.J.Coelli, 1995. A Model for Technical Inefficiency Effects in a Stochastic Frontier Production Function for Panel Data. Empirical Economics Vol, 20:325-332

21. Guan H.Wan and George E.Battese, 1992. A Stochastic Frontier Production Function Incoporating Flexible Risk Properties. Paper presented at the Australian Meeting of the Econometric Society, Monash University, Melbourne, 6-8 July 1992

22. Ghosh C and Raychaudhuri, 2010. Measurement of Cost Efficiency in the Case of Rice Production in West Bengal and Andhra Pradesh.

23. Hartono, J. Teori Ekonomi Mikro (Theory of Microeconomics). Analisis Matematis (Mathematical Analysis). Andi Yogyakarta Press.

24. Just, E.R, dan R.D. Pope. 1979. Production Function Estimation and Related Risk Consideration. American Journal Agricultural Economic, 6(2): 276-284.

25. JR.Anderson and WE. Griffiths.1982. Product Risk and Efficient Allocation of Resources. Australian Journal of Agricultural Economics, 26(3): 226-332.

26. Karagiannias, G., et al, 2006. Technical Efficiency of Conventional and Organic Farms: Some Evidence for Milk Production.

27. Kumbhakar, C S. 2002. Specification and Estimation of Production Risk, Risk Preferences and Technical Efficiency. American Journal Agricultural Economic, 84(1) (February 2002): 8-22.

28. Kumbhakar, C.S. and C.A.Knox Lovell, Stochastic Frontier Analysis. Cambridge University Press

29. KumbhaKar, C.S and Tsionas E.G., 2008. Estimation of Cost vs Profit System with and without Technical Inefficiency. Academia Economic Papers. Vol 36:2. Pp. 145-166

30. Sulihanti, S, 2013. "BKP Kementan targetkan tekan konsumsi beras 1.5\% perkapita" (Food Security Agency of the Ministry of Agriculture Targeting Press the Rice Consumption of $1.5 \%$ per capita), Available in www.deptan.go.id.

31. Respati, E, .dkk, 2014. Buletin Konsumsi Pangan Vol 5 no 1 Tahun 2014 (Food Consumption Bulletin Vol 5 No. 1 of 2014). Pusat Data dan Sistem Informasi Pertanian Center for Data and Information System for Agriculture). Sekretaris Jendral Kementrian Pertanian Secretary General of the Ministry of Agriculture).

32. Peter Schmidt and Robert C.Sickles. 1984. Production Frontiers and Panel Data. Journal of Business and Economic Statistics, Vol 2, No 4, (Oct 1984), pp. 367-374 
APPENDIX 1

\begin{tabular}{|c|c|}
\hline Variables & Descriptions \\
\hline Prfo & Actual profit divided by the price of dry milled rice stated in IDR \\
\hline Pbo & The price of seeds normalized by the output price \\
\hline Puo & The price of urea fertilizer normalized by output price \\
\hline PZAo & The price of ZA fertilizer normalized by output price \\
\hline PPSo & The price of NPK Phonska fertilizer normalized by output price \\
\hline PSPo & The price of SP36 fertilizer normalized by output price \\
\hline Poo & The price of organic fertilizer normalized by output price \\
\hline PTKo & Labor wages of men and women normalized by the output price \\
\hline POBKo & Solid pesticide price normalized by the output price \\
\hline POBLO & Liquid pesticide price normalized by the output price \\
\hline Z10 & Rent cost / land rent normalized by the output price \\
\hline Z2o & Rent cost of tractor normalized by the output price \\
\hline Dtehn & Dummy from the application of technology \\
\hline leff & Technical inefficiency \\
\hline Dmt & Dummy growing season \\
\hline HPP & Government Purchase Price \\
\hline Px & Input price \\
\hline leff Pend & The impact of education on inefficiency \\
\hline leff PR & The impact of the risk behavior on inefficiency \\
\hline HT & Hand tractor \\
\hline Sbbpr & Share of expenditure for the purchase of seed towards profits \\
\hline Sbupr & Share of expenditure for the purchase of urea fertilizer towards profits \\
\hline Sbzapr & Share of expenditure for the purchase of ZA fertilizer towards profits \\
\hline Sbpspr & Share of expenditure for the purchase of NPK Phonska fertilizer towards profits \\
\hline Sbsppr & Share of expenditure for the purchase of SP36 fertilizer towards profits \\
\hline Sbopr & Share of expenditure for the purchase of organic fertilizer towards profits \\
\hline Sbtkpr & Share of expenditure for labor towards profits \\
\hline Sbobkpr & Share of expenditure for the purchase of solid pesticide towards profits \\
\hline Sboblpr & Share of expenditure for the purchase of liquid pesticide towards profits \\
\hline Sbz1pr & Share of expenditure for land rent/tax towards profits \\
\hline Sbz2pr & Share of expenditure for tractor rent towards profits \\
\hline Sypr & Share for output towards profits \\
\hline Py & Output price \\
\hline
\end{tabular}

\section{APPENDIX 2}

Table 2 - Use of Seed ( $\mathrm{Kg} / \mathrm{ha}$ ) Based on the Behavior of Risk

\begin{tabular}{lllll}
\hline Seasons & Risk Averter & Risk Neutral & Risk Taker & Suggestions \\
\hline \hline Rainy & 12.00 & 11.73 & 13.79 & 15 \\
Dry & 12.00 & 12.54 & 13.61 & 15 \\
\hline
\end{tabular}

Table 3 - The Use of Fertilizers ( $\mathrm{kg} / \mathrm{ha}$ ) on Rainy season

\begin{tabular}{lllll}
\hline Fertilizers & Risk Averter & Risk Neutral & Risk Taker & Suggestions \\
\hline \hline Rainy Season & & & & \\
Urea & 297.63 & 362.22 & 302.04 & 300 \\
ZA & 107.10 & 258.33 & 162.72 & 200 \\
Phonska & 161.20 & 242.00 & 243.86 & 200 \\
SP36 & 121.65 & 10.12 & 24.54 & 150 \\
Organic & 247.28 & 192.04 & 322.51 & 500 \\
\hline
\end{tabular}

Table 4 - The Use of Labors (Man-day)

\begin{tabular}{lllll}
\hline Seasons & Tenaga Kerja & Risk Averter & Risk Neutral & Risk Taker \\
\hline \hline Rainy & Male & 70 & 79 & 83 \\
& Female & 64 & 73 & 75 \\
Dry & Male & 70 & 77 & 81 \\
& Female & 64 & 61 & 68 \\
\hline
\end{tabular}


Table 5 - The Use of Solid Pesticides (kg)

\begin{tabular}{llll}
\hline Seasons & Risk Averter & Risk Neutral & Risk Taker \\
\hline \hline Rainy & 9.77 & 11.65 & 6.17 \\
Dry & 9.74 & 11.58 & 6.47 \\
\hline
\end{tabular}

Table 6 - The Use of Liquid Pesticides (liters)

\begin{tabular}{llll}
\hline Seasons & Risk Averter & Risk Neutral & Risk Taker \\
\hline \hline Rainy & 2.81 & 1.68 & 1.13 \\
\hline Dry & 2.82 & 4.24 & 2.62 \\
\hline
\end{tabular}

Table 7 - Profits Based on Farmers Risk Behavior on Rainy Season (IDR)

\begin{tabular}{llll}
\hline Variables & Risk Averter & Risk Neutral & Risk Taker \\
\hline \hline Total Cost & $6,616,782$ & $8,574,596$ & $8,978,027$ \\
Revenue & $26,344,580$ & $35,711,111$ & $30,801,229$ \\
Profit & $19,727,798$ & $27,136,515$ & $21,823,202$ \\
\hline
\end{tabular}

Table 8 - Profits Based on Farmers Risk Behavior on Dry Season (IDR)

\begin{tabular}{llll}
\hline Variables & Risk Averter & Risk Neutral & Risk Taker \\
\hline \hline Total Cost & $6,779,544$ & $8,249,077$ & $9,230,907$ \\
Revenue & $26,949,306$ & $34,222,222$ & $36,662,980$ \\
Profit & $20,169,763$ & $25,973,145$ & $27,432,073$ \\
\hline
\end{tabular}

\section{APPENDIX 3}

(1) Inprfo $=\mathrm{A} 0+\mathrm{A} 1^{*} \operatorname{InPBo}+\mathrm{A} 2^{*} \operatorname{InPUo}+\mathrm{A} 3^{*} \operatorname{InPZAo}+\mathrm{A} 4^{*} \operatorname{InPPSo}+\mathrm{A} 5^{*} \operatorname{InPSPo}+\mathrm{A} 6^{*} \ln \mathrm{POo}+\mathrm{A} 7^{*} \ln \mathrm{PTKo}+$

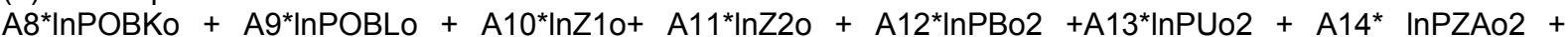

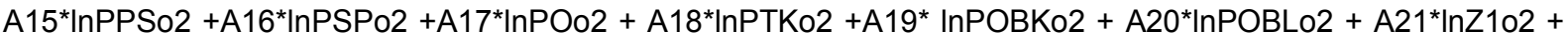

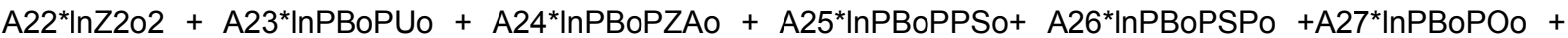
A28*InPBoPTKo +A29*InPBoPOBKo + A30* InPBoPOBLo + A31*InPBoZ1o + A32*InPBoZ2o + A33*InPUoPZAo+ A34*InPUoPPSo + A35*InPUoPSPo + A36*InPUoPOo + A37*InPUoPTKo + A38*InPUoPOBKo + A39*InPUoPOBLo + A40*InPUoZ10 + A41*InPUoZ2o + A42*InPZAoPPSo + A43*InPZAoPSPo + A44*InPZAoPOo + A45*InPZAoPTKo + A46* $\ln P Z A o P O B K o+A 47^{*} \ln P Z A o P O B L o+A 48^{*} \ln P Z A o Z 10+$ A49*InPZAoZ2o + A50*InPPSoPSPo + A51*InPPSoPOo + A52*InPPSoPTKo + A53*InPPSoPOBKo + A54*InPPSoPOBLo + A55*InPPSoZ1o + A56*InPPSoZ2o + A57*InPSPoPOo + A58*InPSPoPTKo + A59*InPSPoPOBKo + A60*InPSPoPOBLo + A61*InPSPoZ10 + A62*InPSPoZ2o + A63*InPOoPTKo + A64*InPOoPOBKo + A65*InPOoPOBLo + A66*InPOoZ10 + A67*InPOoZ2o + A68*InPTKoPOBKo + A69*InPTKoPOBLo + A70*InPTKoZ10+ A71*InPTKoZ2o + A72* InPOBKoPOBLo + A73*InPOBKoZ1o + A74*InPOBKoZ2o + A75*InPOBLoZ1o +A76*InPOBLoZ2o + A77*LNz1oz2o+ A78*DTEHN+A79*IEFF+ A80*dmt (2) $\quad S b b p r=B_{0}+B_{1}{ }^{*} \ln P B o+B_{2}{ }^{*} \ln P U o+B_{3}{ }^{*} \ln P Z A o+B_{4}{ }^{*} \ln P P S o+B_{5}{ }^{*} \ln P S P o+B_{6}{ }^{*} \ln P O_{0}+B_{7}{ }^{*} \ln P K_{0}+$ $\mathrm{B}_{8}{ }^{*} \ln P O B K o+\mathrm{B}_{9}^{*} \ln P O B L o+\mathrm{B}_{10}{ }^{*} \operatorname{lnZ} 10+\mathrm{B}_{11}{ }^{*} \ln Z 20+\mathrm{B}_{12}{ }^{*} \mathrm{dtehn}+\mathrm{B}^{*} 3^{*} \ln$ eff $\mathrm{B}_{14}{ }^{*} \mathrm{dmt}$

(3) Sbupr $=\mathrm{C}_{0}+\mathrm{C}_{1}{ }^{*} \ln \mathrm{PBo}+\mathrm{C}_{2}{ }^{*} \ln \mathrm{PUo}+\mathrm{C}_{3}{ }^{*} \ln \mathrm{PZAo}+\mathrm{C}_{4}{ }^{*} \ln P P S o+\mathrm{C}_{5}{ }^{*} \ln \mathrm{BSPo}+\mathrm{C}_{6}{ }^{*} \ln \mathrm{BOo}+\mathrm{C}_{7}{ }^{*} \ln \mathrm{nPKo}+$ $\mathrm{C}_{8}{ }^{*} \ln P O B K o+\mathrm{C}_{9}{ }^{*} \ln P O B L o+\mathrm{C}_{10}{ }^{*} \operatorname{lnZ10}+\mathrm{C}_{11}{ }^{*} \ln Z 20+\mathrm{C}_{12}{ }^{*} \mathrm{dtehn}+\mathrm{C}_{13}{ }^{*} \operatorname{lneff}+\mathrm{C}_{14}{ }^{*} \mathrm{dmt}$

(4) Sbzapr $=D_{0}+D_{1}{ }^{*} \ln P B o+D_{2}^{*} \ln P U o+D_{3}{ }^{*} \ln P Z A o+D_{4}{ }^{*} \ln P P S o+D_{5}{ }^{*} \ln P S P o+D_{6}{ }^{*} \ln P O o+D_{7}^{*} \ln P T K o+$ $\mathrm{D}_{8}{ }^{*} \ln P O B K o+\mathrm{D}_{9}{ }^{*} \ln P O B L o+\mathrm{D}_{10}{ }^{*} \operatorname{lnZ10}+\mathrm{D}_{11}{ }^{*} \operatorname{lnZ20}+\mathrm{D}_{12}{ }^{*} \mathrm{dtehn}+\mathrm{D} 13^{*} \ln$ eff $+\mathrm{D}_{14}{ }^{*} \mathrm{dmt}$

(5) $\quad$ b bpspr $=E_{0}+E_{1}{ }^{*} \ln P B o+E_{2}{ }^{*} \ln P U o+E_{3}^{*} \ln P Z A o+E_{4}{ }^{*} \ln P P S o+E_{5}{ }^{*} \ln P S P o+E_{6}{ }^{*} \ln P O o+E_{7}{ }^{*} \ln P T K_{0}+$ $E_{8}{ }^{*} \ln P O B K o+E_{9}{ }^{*} \ln P O B L o+E_{10}{ }^{*} \ln Z 10+E_{11}{ }^{*} \ln Z 20+E_{12}{ }^{*} \mathrm{DTEHN}+\mathrm{E}_{13}{ }^{*} \mathrm{dmt}+\mathrm{E}_{14}{ }^{*} \mathrm{dmt}$

(6) $\quad$ bbsppr $=\mathrm{F}_{0}+\mathrm{F}_{1}{ }^{*} \ln \mathrm{PBo}+\mathrm{F}_{2}{ }^{*} \ln \mathrm{nUo}+\mathrm{F}_{3}{ }^{*} \ln \mathrm{PZAo}+\mathrm{F}_{4}{ }^{*} \ln \mathrm{PPSo}+\mathrm{F}_{5}{ }^{*} \ln \mathrm{PSPo}+\mathrm{F}_{6}{ }^{*} \ln \mathrm{OOo}+\mathrm{F}_{7}{ }^{*} \ln \mathrm{nTKo}+$ $F_{8}^{*} \ln P O B K o+F_{9}^{*} \ln P O B L o+F_{10}{ }^{*} \ln Z 10+F_{11}{ }^{*} \ln Z 20+F_{12}{ }^{*} D T E H N+F 13^{*} \ln e f f+F 14^{*} d m t$

(7) Sbopr $=\mathrm{G}_{0}+\mathrm{G}_{1}{ }^{*} \ln \mathrm{PBo}+\mathrm{G}_{2}{ }^{*} \ln \mathrm{PUo}+\mathrm{G}_{3}{ }^{*} \ln \mathrm{PZAo}+\mathrm{G}_{4}{ }^{*} \ln P P S o+\mathrm{G}_{5}{ }^{*} \ln \mathrm{PSPo}+\mathrm{G}_{6}{ }^{*} \ln \mathrm{POo}+\mathrm{G}_{7}{ }^{*} \ln \mathrm{PTKo}+$ $\mathrm{G}_{8}{ }^{*} \ln P O B K o+\mathrm{G}_{9}{ }^{*} \ln P O B L o+\mathrm{G}_{10}{ }^{*} \operatorname{lnZ10}+\mathrm{G}_{11}{ }^{*} \operatorname{lnZ20}+\mathrm{G}_{12}{ }^{*} \mathrm{DTEHN}+\mathrm{G}_{13}{ }^{*} \operatorname{lenff}+\mathrm{G}_{14}{ }^{*} \mathrm{dmt}$

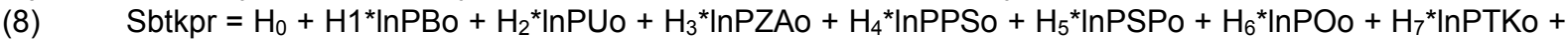
$\mathrm{H}_{8}{ }^{*} \ln P O B K o+\mathrm{H}_{9}{ }^{*} \ln P O B L o+\mathrm{H}_{10}{ }^{*} \operatorname{lnZ} 10+\mathrm{H}_{11}{ }^{*} \ln Z 20+\mathrm{H}_{12}{ }^{*} \mathrm{dtehn}+\mathrm{H}_{13}{ }^{*} \ln e f f+\mathrm{H}_{14}{ }^{*} \mathrm{dmt}$

(9) $\quad$ Sbobkpr $=I_{0}+I_{1}{ }^{*} \operatorname{lnPBo}+I_{2}{ }^{*} \operatorname{lnPUo}+I_{3}{ }^{*} \ln P Z A o+I_{4}{ }^{*} \ln P P S o+I_{5}{ }^{*} \operatorname{lnPSPo}+I_{6}{ }^{*} \operatorname{lnPOo}+I_{7}{ }^{*} \operatorname{lnPTKo}+$ $I_{8}^{*} \operatorname{lnPOBKo}+I_{9}^{*} \ln P O B L o+I_{10}{ }^{*} \ln Z 10+I_{11}{ }^{*} \ln Z 20+I_{12}{ }^{*} \mathrm{DTEHN}+\mathrm{I}_{13^{*}} \ln \operatorname{lff}+\mathrm{I}_{14}{ }^{*} \mathrm{dmt}$

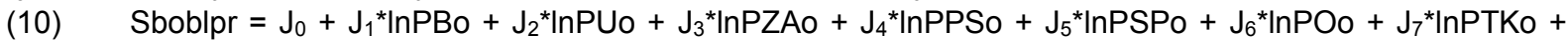
$\mathrm{J}_{8}{ }^{*} \ln P O B K o+J_{9}{ }^{*} \ln P O B L o+J_{10}{ }^{*} \ln Z 10+J_{11}{ }^{*} \ln Z 20+J_{12}{ }^{*}$ dtehn $+J_{13}{ }^{*} \operatorname{lneff}+J_{14}{ }^{*} \mathrm{dmt}$

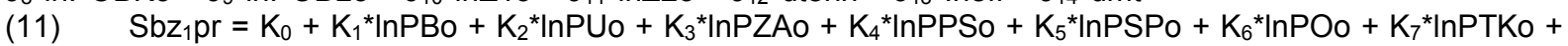
$\mathrm{K}_{8}{ }^{*} \ln \mathrm{POBKo}+\mathrm{K}_{9}{ }^{*} \operatorname{lnPOBLo}+\mathrm{K}_{10}{ }^{*} \ln Z 10+\mathrm{K}_{11}{ }^{*} \mathrm{Z} 2 \mathrm{O}+\mathrm{K}_{12}{ }^{*} \mathrm{dtehn}+\mathrm{K}_{13}{ }^{*} \ln$ eff $\mathrm{K}_{14}{ }^{*} \mathrm{dmt}$

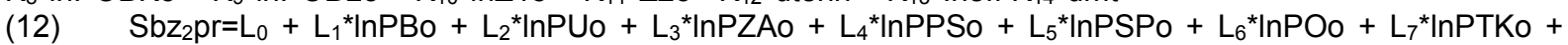
$\mathrm{L}_{8}{ }^{*} \operatorname{lnPOBKo}+\mathrm{L}_{9}{ }^{*} \ln P O B L_{0}+\mathrm{L}_{10}{ }^{*} \ln Z 10+\mathrm{L}_{11}{ }^{*} \ln Z 20+\mathrm{L}_{12}{ }^{*} \mathrm{DTEHN}+\mathrm{L}_{13}{ }^{*} \mathrm{IEFF}+\mathrm{L}_{14}{ }^{*} \mathrm{Dmt}$

(13) $\quad$ Sypr $=M_{0}+M_{1}{ }^{*} \ln P B o+M_{2}{ }^{*} \ln P U o+M_{3}{ }^{*} \ln P Z A o+M_{4}{ }^{*} \ln P P S o+M_{5}{ }^{*} \ln P S P o+M_{6}{ }^{*} \ln P O o+M_{7}{ }^{*} \ln P T K o+$ $\mathrm{M}_{8}{ }^{*} \operatorname{InPOBKo}+\mathrm{M}_{9}{ }^{*} \operatorname{InPOBLo}+\mathrm{M}_{10}{ }^{*} \operatorname{lnZ10}+\mathrm{M}_{11}{ }^{*} \operatorname{lnZ20}+\mathrm{M}_{12}{ }^{*} \mathrm{Py}+\mathrm{M}_{13}{ }^{*} \mathrm{DTEHN}+\mathrm{M}_{14}{ }^{*} \mathrm{IEFF}+\mathrm{M}_{15}{ }^{*} \mathrm{Dm}$ 
RJOAS, 10(58), October 2016

\section{APPENDIX 4}

Table 11 - Share of Expenditure for Inputs towards Profit

\begin{tabular}{|c|c|c|c|c|c|c|c|c|c|c|c|}
\hline \multirow[b]{2}{*}{ Variables } & \multicolumn{6}{|c|}{ Share of Input Expenditure towards Profit } & \multicolumn{5}{|c|}{ Share of Input Expenditure towards Profit } \\
\hline & Seed & $\begin{array}{l}\text { Urea } \\
\text { Fertilizer }\end{array}$ & $\begin{array}{l}\text { ZA } \\
\text { Fertilizer }\end{array}$ & $\begin{array}{l}\text { NPK Ps } \\
\text { Fertilizer }\end{array}$ & $\begin{array}{l}\text { SP36 } \\
\text { Fertilizer }\end{array}$ & $\begin{array}{l}\text { Organic } \\
\text { Fertilizer }\end{array}$ & Labor & $\begin{array}{l}\text { Solid } \\
\text { Pesticides }\end{array}$ & $\begin{array}{l}\text { Liquid } \\
\text { Pesticides }\end{array}$ & $\begin{array}{l}\text { Rent/ } \\
\text { Tax of land }\end{array}$ & $\begin{array}{l}\text { Rent of } \\
\text { tractor }\end{array}$ \\
\hline Intercept & 0.1144 & 0.273 & -0.473 & -0.641 & -0.81 & -1.09 & 1.078 & 0.2145 & -0.06 & 0.087 & 0.0454 \\
\hline InPBo & -0.29 & 0.049 & 0.078 & 0.063 & 0.09 & -0.019 & 0.013 & 0.0028 & 0.007 & $1.28 \mathrm{E}-06$ & 0.00226 \\
\hline InPUo & 0.049 & -0.561 & 0.176 & 0.1318 & 0.1399 & 0.0166 & 0.0442 & -0.0054 & 0.005 & 0.005 & -0.0014 \\
\hline InZAo & 0.078 & 0.176 & -0.415 & 0.1255 & -0.148 & -0.018 & 0.181 & -0.0115 & -0.00788 & 0.0322 & 0.0074 \\
\hline InPPSo & 0.063 & 0.1318 & 0.1255 & -0.522 & 0.1169 & -0.1597 & 0.2226 & -0.0126 & 0.005 & 0.0226 & 0.0067 \\
\hline InPSPo & 0.09 & 0.1399 & -0.148 & 0.1169 & -0.4479 & -0.033 & 0.258 & 0.00168 & 0.00052 & 0.0167 & 0.0025 \\
\hline InPOo & -0.019 & 0.0166 & -0.018 & -0.1597 & -0.033 & -0.272 & 0.2765 & 0.1689 & -0.0397 & 0.023 & 0.057 \\
\hline InPTKo & 0.013 & 0.0442 & 0.181 & 0.2226 & 0.258 & 0.2765 & -0.992 & -0.023 & 0.006 & 0.0066 & 0.0074 \\
\hline InPOBKo & 0.0028 & -0.0054 & -0.0115 & -0.0126 & 0.00168 & 0.1689 & -0.023 & -0.147 & 0.00229 & 0.008 & 0.0159 \\
\hline InPOBLo & 0.007 & 0.005 & -0.00788 & 0.005 & 0.00052 & -0.0397 & 0.006 & 0.00229 & 0.00149 & 0.0054 & 0.0143 \\
\hline $\ln Z 10$ & 0.000001276 & 0.005 & 0.0322 & 0.0226 & 0.0167 & 0.023 & 0.0066 & 0.008 & 0.0054 & -0.1225 & 0.0022 \\
\hline $\ln Z 20$ & 0.00226 & -0.0014 & 0.0074 & 0.0067 & 0.0025 & 0.057 & 0.0074 & 0.0159 & 0.0143 & 0.0022 & -0.114 \\
\hline Dummy Application of Technology (Dtehn) & 0.0032 & -0.0024 & -0.037 & -0.00675 & -0.00845 & 0.0872 & -0.00094 & -0.055 & -0.035 & 0.0015 & 0.00697 \\
\hline leff & -0.04 & 0.181 & 0.361 & 0.2563 & 0.2411 & 0.965 & -0.465 & 0.02697 & -0.00655 & -0.1 & -0.094 \\
\hline Dummy rainy and dry seasons (Dm) & -0.0027 & -0.01144 & 0.0128 & 0.0008 & 0.179 & 0.039 & 0.0369 & 0.0175 & -0.3014 & -0.00067 & -0.0014 \\
\hline
\end{tabular}

${ }^{* * * *},{ }^{* * *},{ }^{* *},{ }^{*} ;$ Convidence level at $99 \%, 97.5 \%, 95 \%$ and $90 \%$ 